\title{
The WW II Saint-Pabu German Radar Camp-2
}

\author{
G. T. Tomezzoli ${ }^{1}$, S. Colliou ${ }^{2}$ \\ ${ }^{1}$ Etno-ArchaeologicalObservatory, Munich, Germany \\ ${ }^{2}$ Les Bunkers de Saint-PABU, Saint-Pabu, France \\ Email: gt21949@gmx.de, bunkers-saint-pabu@orange.fr
}

How to cite this paper: Tomezzoli, G. T., \& Colliou, S. (2018). The WW II Saint-Pabu German Radar Camp-2. Archaeological Discovery, 6, 88-102.

https://doi.org/10.4236/ad.2018.62006

Received: February 9, 2018

Accepted: April 9, 2018

Published: April 12, 2018

Copyright $\odot 2018$ by authors and Scientific Research Publishing Inc. This work is licensed under the Creative Commons Attribution International License (CC BY 4.0).

http://creativecommons.org/licenses/by/4.0/

\section{(c) (i) Open Access}

\begin{abstract}
It is a pleasure to observe that the hope for further studies on the WW II German radar camp of Saint-Pabu (Brittany-FR) formulated in a previous publication has materialized. The Doll's archive provided new documentation from the RAF Operations Rhubarb permitting to reconstruct the first camp activities and giving hints about the daily life of its personnel. The excavation of the L479 Anton for day and night fighter control clarified architectural aspects of its construction and permitted the recuperation and examination of original German military equipments. But, further questions remain open for investigation.
\end{abstract}

\section{Keywords}

Saint-Pabu, German, Radar, Surveillance, Atlantic Wall, Finistère, France

\section{Introduction}

At the end of a previous publication (Tomezzoli \& Colliou, 2017) concerning the WW II German radar camp of Saint-Pabu (Brittany-FR), it was observed that some issues remained open: the actual number of radars in service at the camp, the timing of their deployment and substitution, the purpose of the camp improvement, and it was formulated the hope that the information in said publication could form the basis for further studies. Therefore, it is a pleasure to see how the studies actually progressed.

\section{Saint-Pabu Radar Camp—Early Evolution}

The Doll's archive preserves images from the RAF Operations Rhubarb and maps that showed the Saint-Pabu radar camp, indicated as Target VI/1, in the period June 1941-January 1942. An image of $16^{\text {th }}$ June 1941 showed no trace of radars or constructions in the fields still under cultivation. In an image of $18^{\text {th }}$ December 1941 the camp installations appear fresh and the connection cable 
trenches well-marked. The map C19 of $23^{\text {rd }}$ November 1941 showed at the camp two radar Freya, coded F50 and F51 and one radar WürzburgFuMG 39T, coded $W$ 510. C.I.U. Plan N91065 (Figure 1) shows the situation of the camp on $10^{\text {th }}$ January 1942. On $18^{\text {th }}$ January 1942 a Kriegsmarine radar Freya was installed on the north side of the camp. One sheet of the Chazette's Collection of Maintenance Sheets of the Kriegsmarine radars in the Finistère, mentioned the presence at Saint-Pabu of a marine radar FuMG 41 AEG AVE 55, listed also as 387 AEG $A V E$ 55, under the cover name $F M$ 24. It was installed on $18^{\text {th }}$ January 1942 (Blanchard, 2017).

Target VI/1 (Figure 2), on $10^{\text {th }}$ January 1942, consisted of a principal site C and five secondary sites A-B, D-F connected by buried cables. The sites A-F were spread on the municipality of Saint-Pabu, on the two adjacent localities of Le Bous and TevenarReut.

Figure 1(a) is particularly touching because the high image quality permitted, by enlargements, to distinguish parked vehicles, soldiers and an officer involved in their daily activities at site $\mathrm{C}$ in the faraway 3rd January 1942 (Figure 3).

Site A: (about $48^{\circ} 33^{\prime} 57^{\prime \prime} \mathrm{N}, 4^{\circ} 37^{\prime} 17^{\prime \prime} \mathrm{W}$ ) at about 400 yards South-West of site C. It consisted of a permanent anti-blast wall protecting the radar FreyaF50 formed by a cabin surmounted by an array antenna. In its proximity was a ground mound standing on a small concrete structure hosting probably a mechanism and/or personnel. A little further, on the side of a scrubby terrain was a mound similar but greater than the precedent wall, covering another structure. A machine gun position completed site A.

Site B: (about $48^{\circ} 33^{\prime} 56^{\prime \prime} \mathrm{N}, 4^{\circ} 37^{\prime} 1^{\prime \prime} \mathrm{W}$ ) positioned at the corner of a small plantation in a curve of a road (actual rue Chateau d'Eau), at about 230 yards

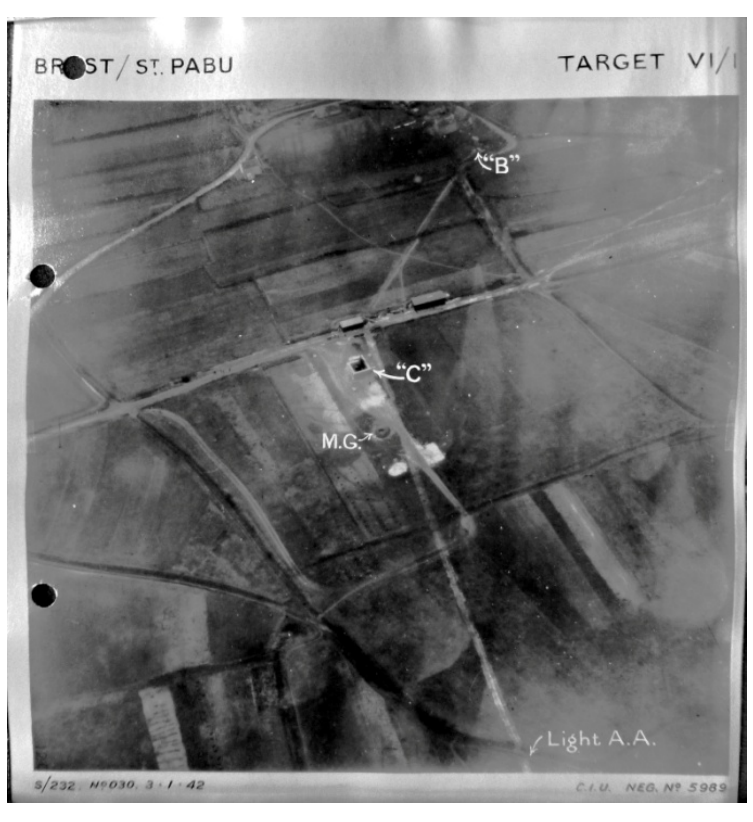

(a)

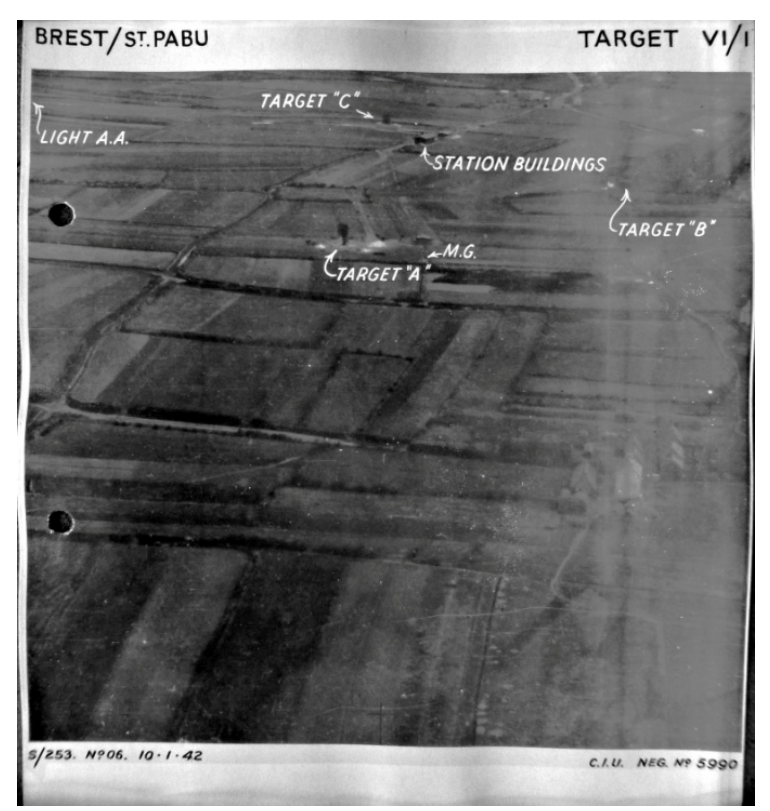

(b)

Figure 1. Brest/Saint-Pabu-Target VI/1: (a) Sites B-C, S/232. No 030. 3-1-1942 C.I.U. Neg. 5989; (b) Sites A-C, S/253. N 06. 10-1-42 C.I.U. Neg. N 5990 (Doll, 2017). 


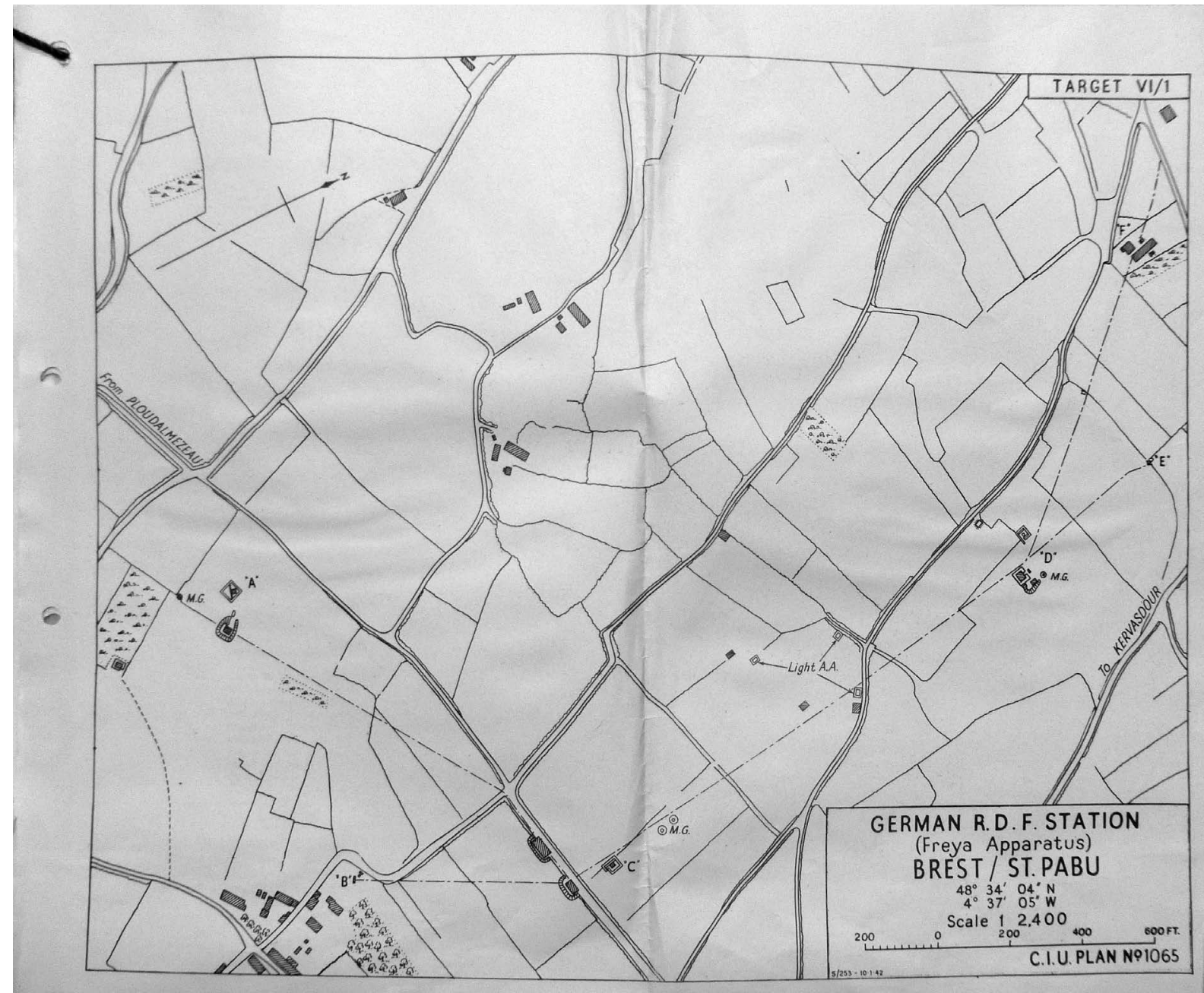

Figure 2. Target VI/1-Saint-Pabu-sites A-F-S/253-10.1.42 (Doll, 2017).

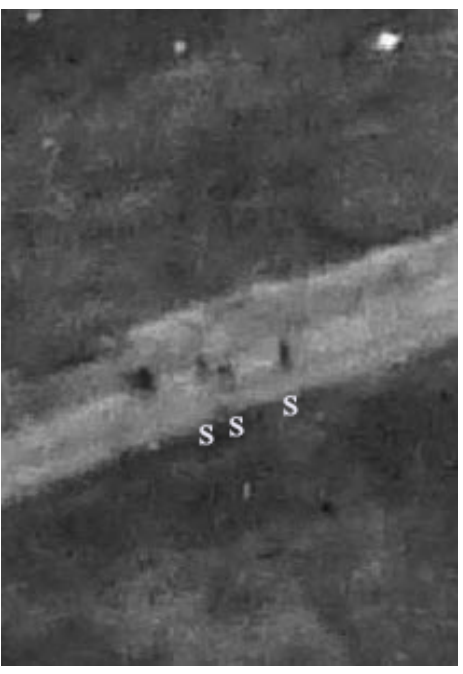

(a)

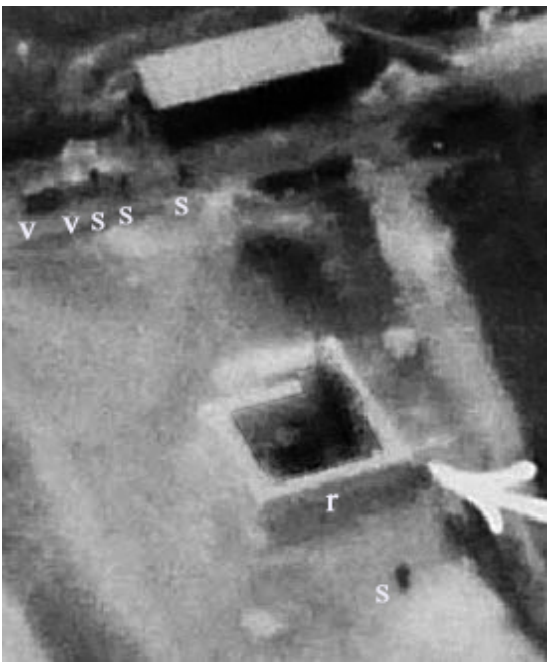

(b)

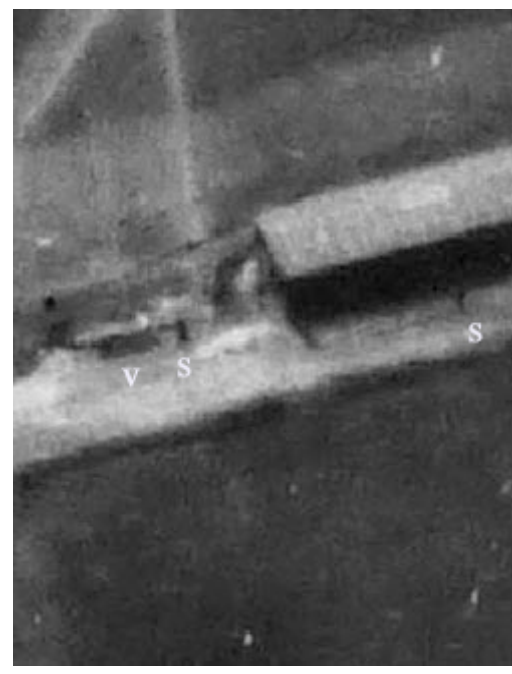

(c)

Figure 3. Enlargements of Figure 1(a). (a) Two soldiers s with backpack proceeded by an officer in dark military uniform; (b) Radar Freya-r, four soldiers and parked vehicles v; (c) Two soldiers s and a parked vehicle v. 
South-South-West of site C. It consisted of a structure frame long and thin with a narrow sloping coverage or roof.

Site C: (about $48^{\circ} 34^{\prime} 3^{\prime \prime} \mathrm{N}, 4^{\circ} 36^{\prime} 59^{\prime \prime} \mathrm{W}$ ) positioned on the two sides of the principal road (actual rue AvelVor). On the North side of the road was the radar FreyaF51 protected by an important concrete, rectangular wall probably superimposed to a $V f$ bunker; near the wall was a circular machine gun position. On the South side of the road were two rectangular barracks (probably personnel lodgements) of temporary nature, protected on three sides by an anti-blast wall.

Site D: (about $48^{\circ} 34^{\prime} 14^{\prime \prime} \mathrm{N}, 4^{\circ} 36^{\prime} 58^{\prime \prime} \mathrm{W}$ ) at about 300 yards at North-North-West of site C. It consisted of a square emplacement containing a "bowl-fire" device corresponding to radar $W$ 510. In its proximity were two rectangular cabins protected by an anti-blast wall. A machine gun position completed site $\mathrm{D}$.

Site E: (about $48^{\circ} 34^{\prime} 18^{\prime \prime} \mathrm{N}, 4^{\circ} 37^{\prime} 0^{\prime \prime} \mathrm{W}$ ) at about 130 yards north of the site D. It consisted of small constructions erected on the hedges at the corner of a field.

Site F: (about $48^{\circ} 34^{\prime} 22^{\prime \prime} \mathrm{N}, 4^{\circ} 37^{\prime} 11^{\prime \prime} \mathrm{W}$ ) at about 280 yards at North-West of the site D. It consisted in an enclosure leaning on the road. It contained a long and narrow construction, a square construction and some little huts probably for the lodgement of Target VI/1 personnel (Blanchard, 2017).

\section{The $L 479$ Excavation}

The construction of an L 479Anton $\left(48^{\circ} 33^{\prime} 58.48^{\prime \prime} \mathrm{N}, 4^{\circ} 37^{\prime} 15.97^{\prime \prime} \mathrm{W}\right)$ (Figure 4 and Figure 5), for hosting a day and night fighter control centre, in the camp started in the first quarter of 1943 and its commissioning took place on $\mathrm{Au}$ gust-September 1943, just one year before the liberation of Saint-Pabu. It was captured by the American forces at the surrender of the camp personnel, without combats. The camp was rapidly transformed in prison camp and placed under the administration of the French Army up to 1947, before to be acquired by the municipality of Saint-Pabu. The major of that time made an inventory of the camp constructions in view of their possible re-utilizations. The $L 479$ became a garage for a plow for a certain period, before to be permanently closed on 2015 (Colliou, 2017).

The excavation of the $L 479$ began on the last quarter of 2017. An excavator

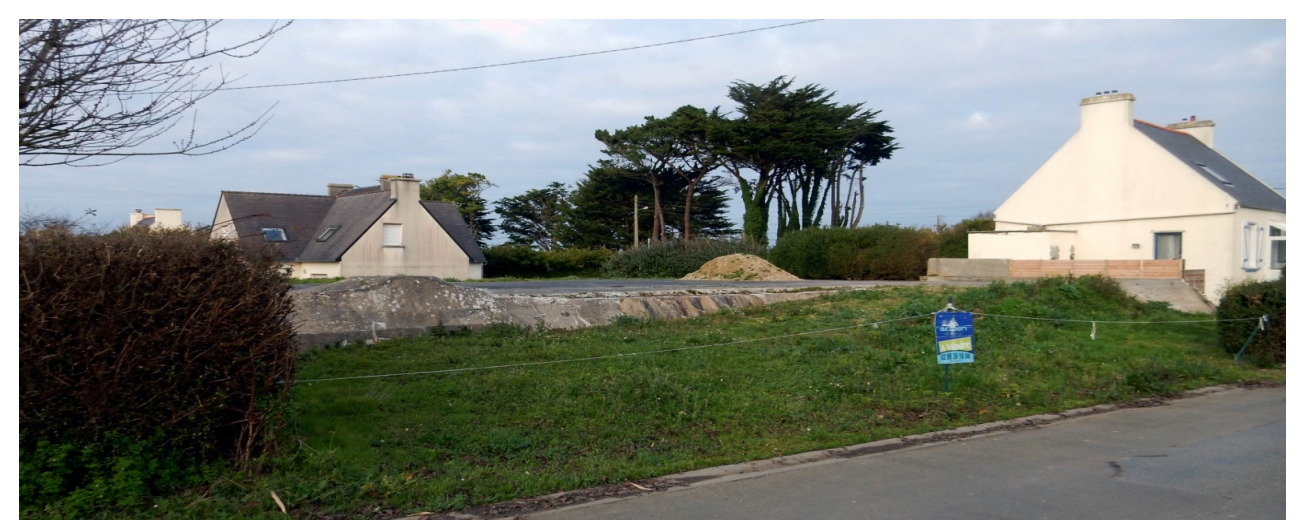

(a) 


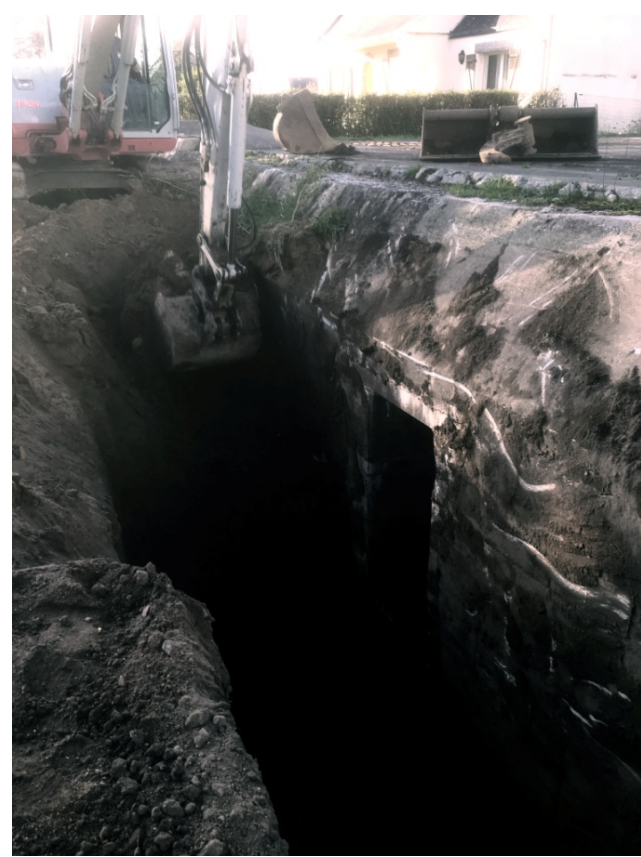

(b)

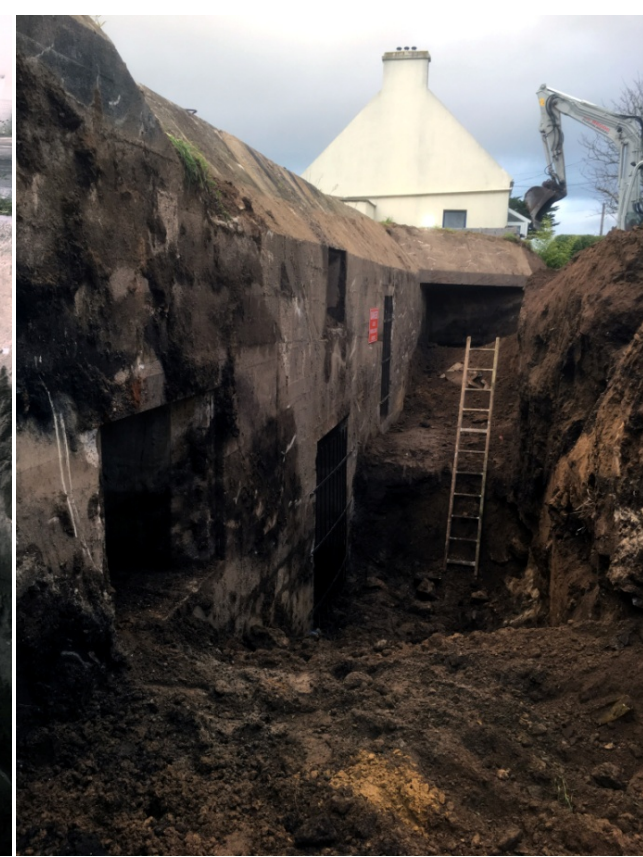

(c)

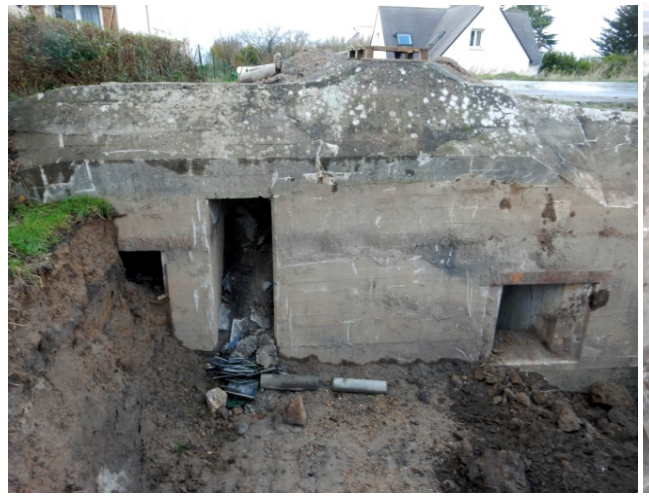

(d)

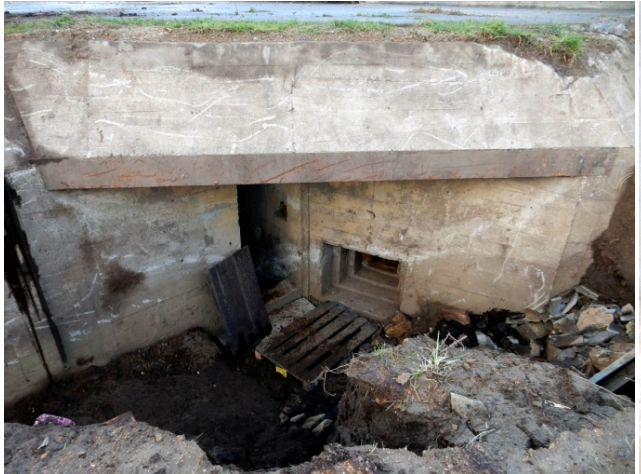

(f)

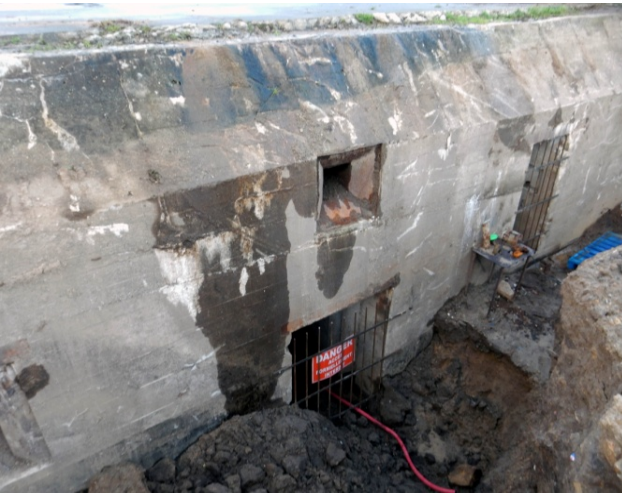

(e)

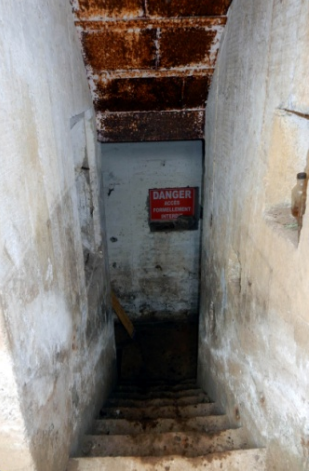

(g)

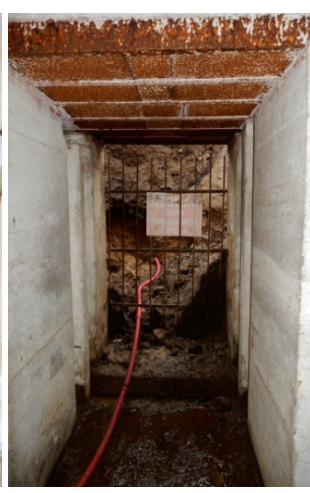

(h)
Figure 4. L 479 excavation: (a) $L 479$ on $5^{\text {th }}$ January 2017, before excavations; (b) Excavation of the facade; (c) Disinterred facade; (d) External observation post entrance and partially obstructed emergency exit; (e) Generator entrance with superimposed generator gas release aperture and on the right personnel entrance; (f) Personnel entrance and louver of the close combat room with splinter guards; (g) Personnel entrance; (h) Generator entrance. 


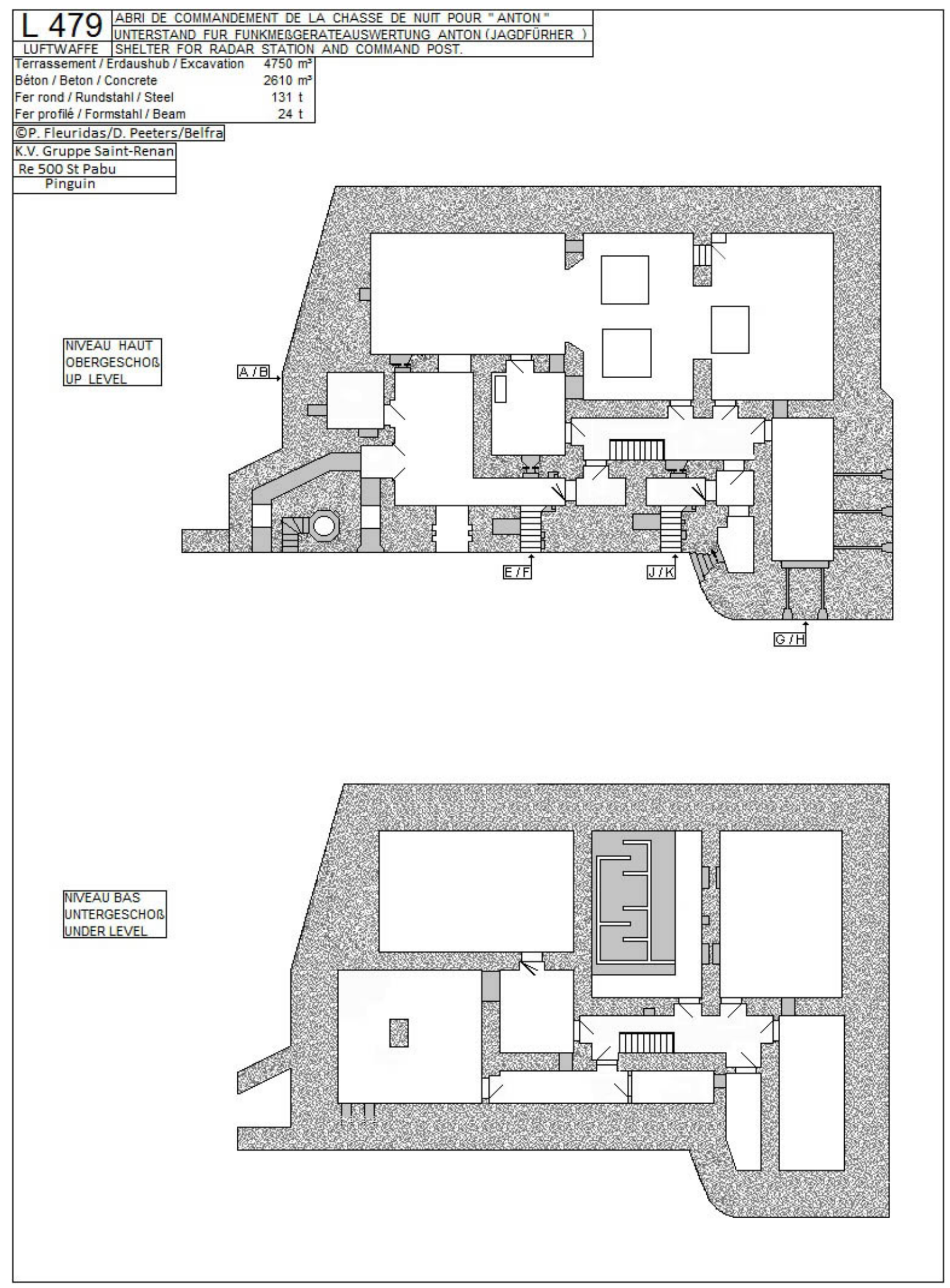

(a) 


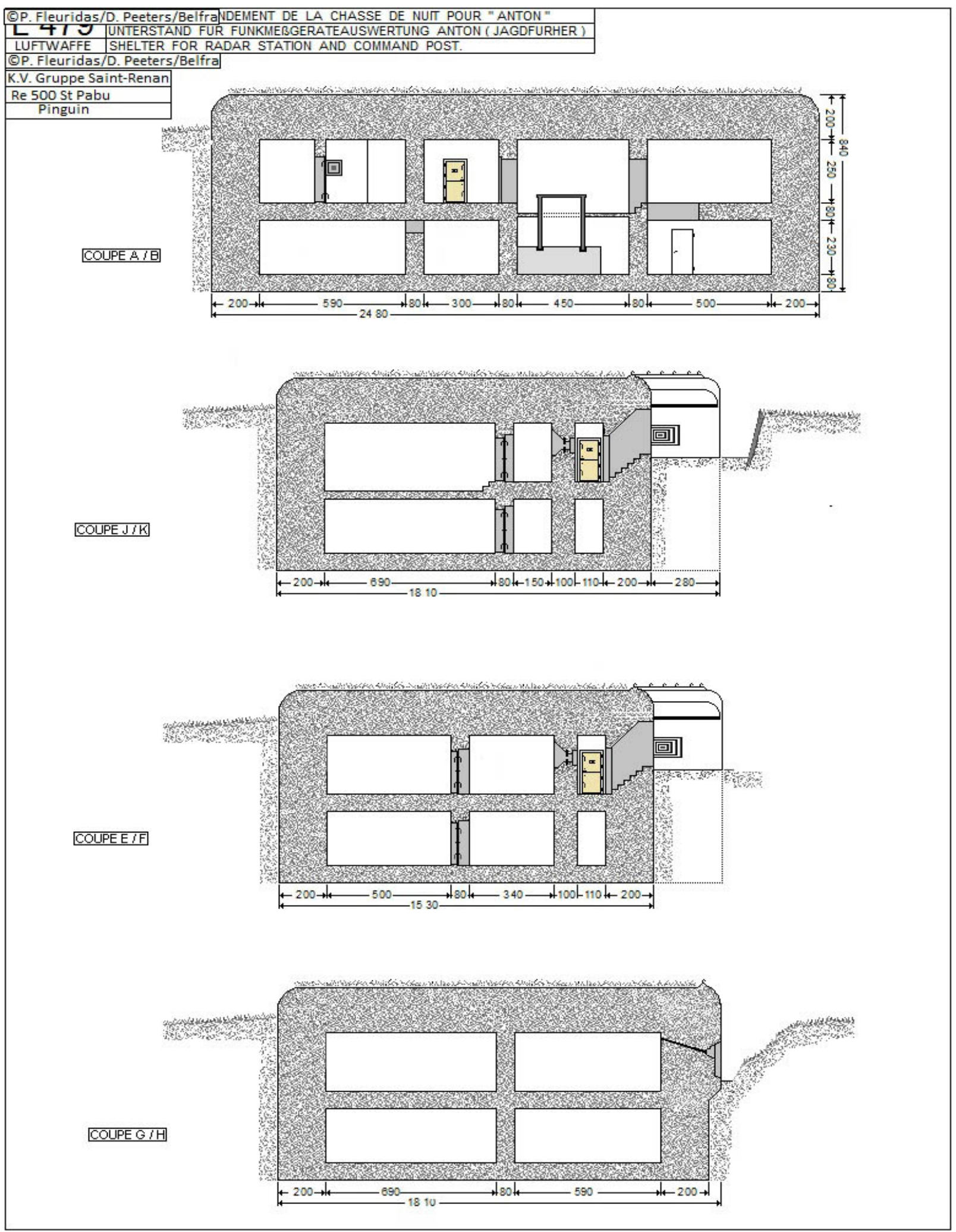

(b)

Figure 5. L 479 plan-(a) Ground floor and lower floor; (b) Vertical sections (Fleuridas, 2017) (for the room identification refers to Rudi, 1988). 
freed the $L 479$ facade and entrances (Figure 4) allowing to access the interior for inspection.

The $L 479$ facade and the coverage appeared well preserved. No stairs for accessing the entrances and no protection wall retained the terrain in front of the entrances. A person accidentally present during the excavation, who seen the $L$ 479 at the moment of the liberation of Saint-Pabu, confirmed that it was relatively far from the principal road and the access to its two personnel entrances was allowed by a gentle gravel slope perpendicular to the façade, leading to a small rectangular courtyard in front of them (Colliou, 2017).

The disinterred facade preserved the louver of the close combat room facing the entrances and covered by a slanted portion of the couverture, the personnel entrances, a lower rectangular entrance for the emergency electrical generator and materials with the superimposed generator gas release aperture, a rectangular aperture near said generator entrance, the external observation post entrance and an emergency exit.

A three stone layers runoff filtration system encircled the $L$ 479. It was composed by a large rubble layer down to the level of the generator entrance, a superimposed 1 meter thick crushed stones layer up to the personnel entrances, and a light finer gravel finishing layer. At the level of the generator entrance was a sump made of big rubble. At the interior, the ground floor was dry, the lower floor was water flooded. $35 \mathrm{~m}^{3}$ of water were emptied without water back. Minor water infiltrations through the antennae passages and a water upwelling through the cable arrival tubes in the telephone exchange room of the lower floor were remarked.

A crawl space, about $60 \mathrm{~cm}$ large assured the insulation from the terrain. It permitted to access all the rooms of the lower floor, and two wells from the crawl space gone up to two apertures about $80 \times 80 \mathrm{~cm}$ for creating a depression between the ground surface and the lower floor, about $8 \mathrm{~m}$ below, ensuring air circulation.

Hatches for cable passage were located in the walls and between the ground floor and the lower floor, but no original cables were present. The $L 479$ was empty. In particular, no rests remained of radios, telephones and the Seeburg tables for representing the positions of foe aircrafts derived by radar information and for driving the German fighter aircrafts against.

The ground floor was covered by a straw layer. Wooden structures obstructed two apertures for the Seeburg tables (Figure 6(a), Figure 6(b) and Figure 6(i)). The walls preserved their original white painting with a black band about $30 \mathrm{~cm}$ height near the floor. A wall preserved the original, official $L 479$ identification: $R$ 500/3, i.e. support point (StP-Stützpunkt) $R$ (enan) 500, construction number 3 (Figure 6(e)). The rusted metallic ceiling let to recognize its original beige colour. The stair between the ground floor and the lower floor was deprived of railing.

The telephone exchange room at the ground floor, covered by debris (Figure 6(d)), reserved the surprise of components of German gas mask filtering cartridges (Figures $7(\mathrm{a})-(\mathrm{k})$ ). Their degraded state did not permit the reading of 
their original printed or engraved codes. However, their morphological characteristics let to identify them as components of filtering cartridges (Filter Einsatz) $F E$ 37, FE 39, FE 41 and FE 42 (Figures 7(b)-(k)). 32 fragments and 2 complete filtering cartridges were discovered.

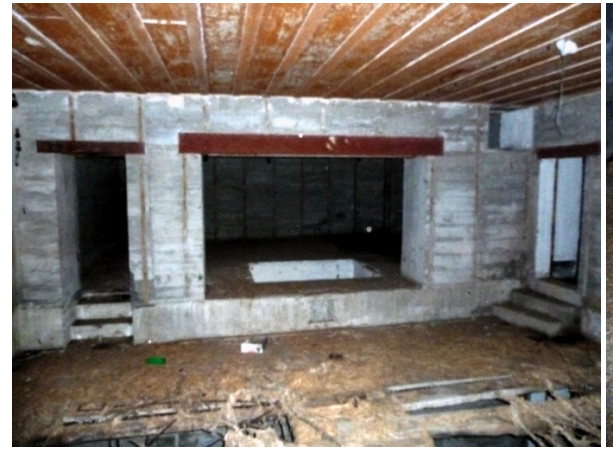

(a)

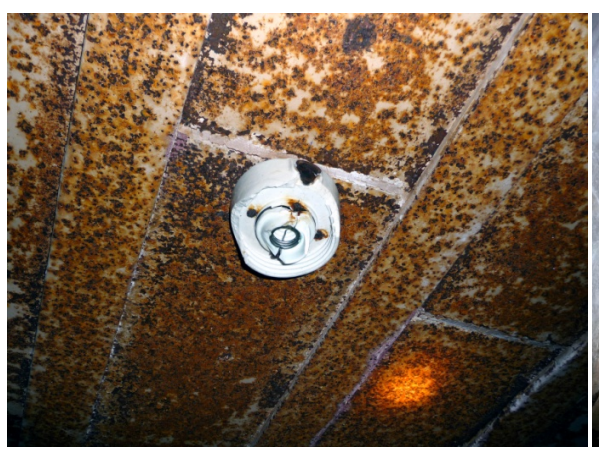

(c)

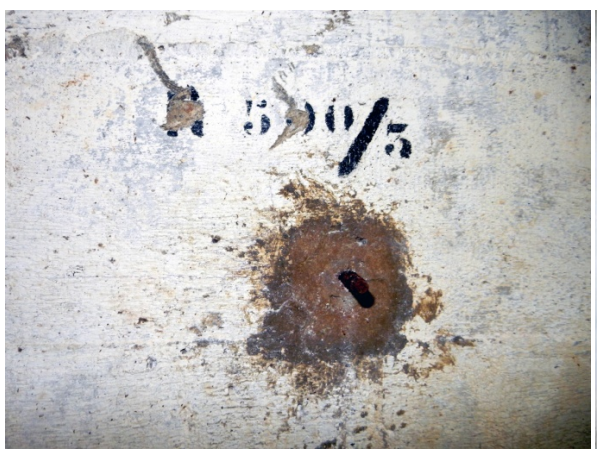

(e)

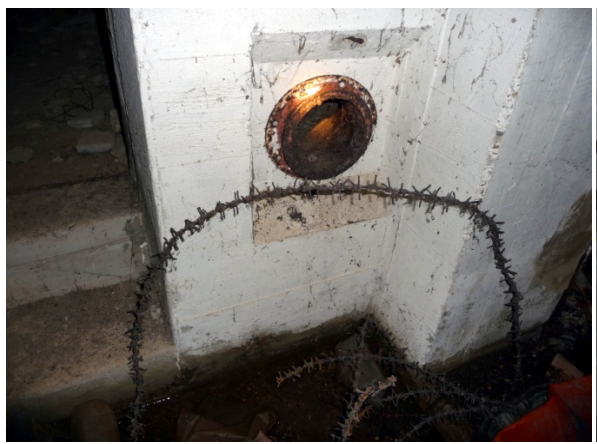

(h)

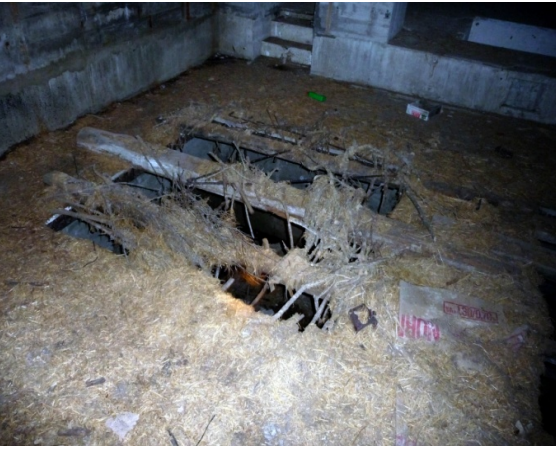

(b)

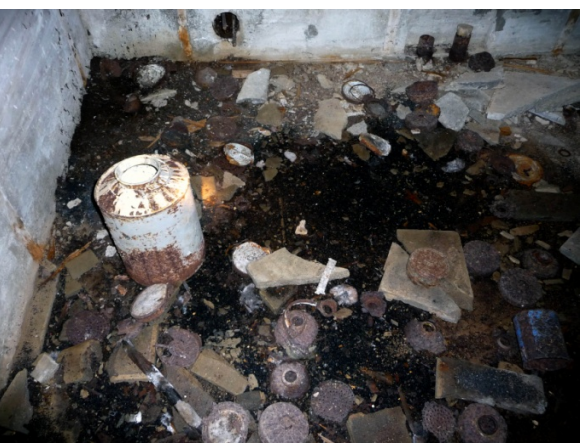

(d)

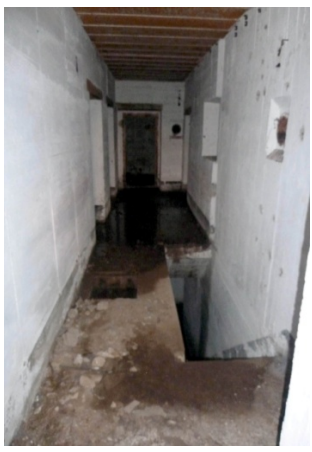

(f)

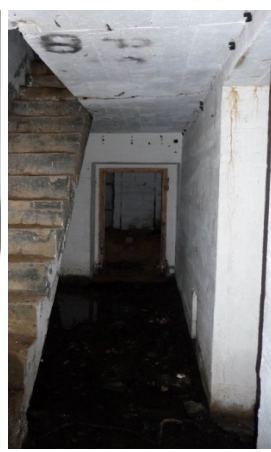

(g)

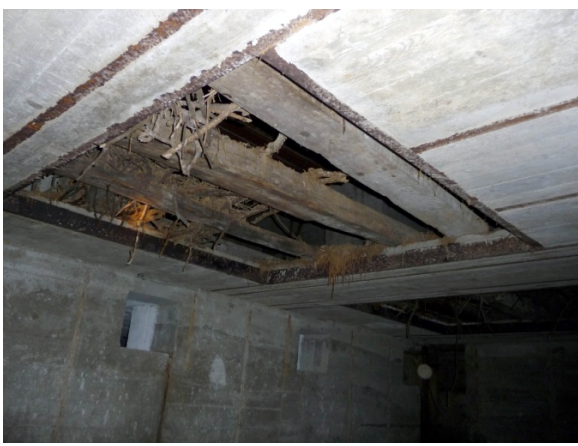

(i) 


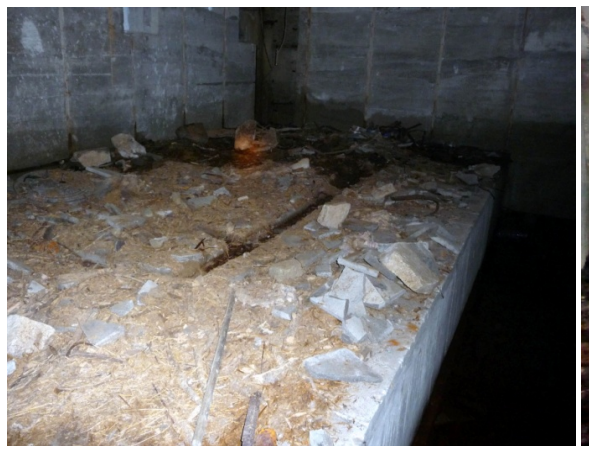

(j)

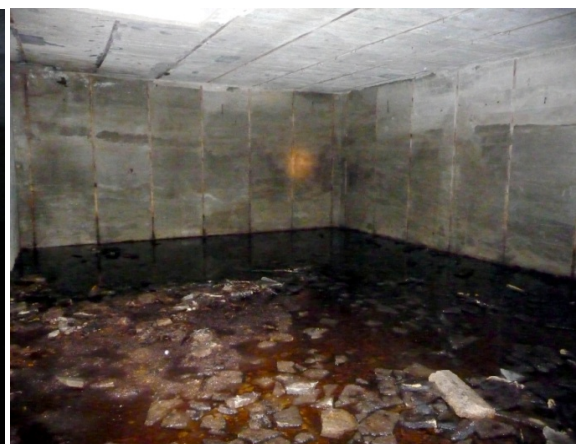

(k)

Figure 6. L 479. (a) Command rooms; (b) Seeburg table aperture obstructed by a wooden structure; (c) Rusted metallic ceiling of the command rooms; (d) Telephone exchange room; (e) Original, official L 479 identification; (f) Stairs to the lower floor; (g) Lower floor flooded by water; (h) barbed wire stretch; (i) Seeburg table apertures obstructed by wooden structures; (j) Seeburg tables support; (k) Lower floor flooded by water.

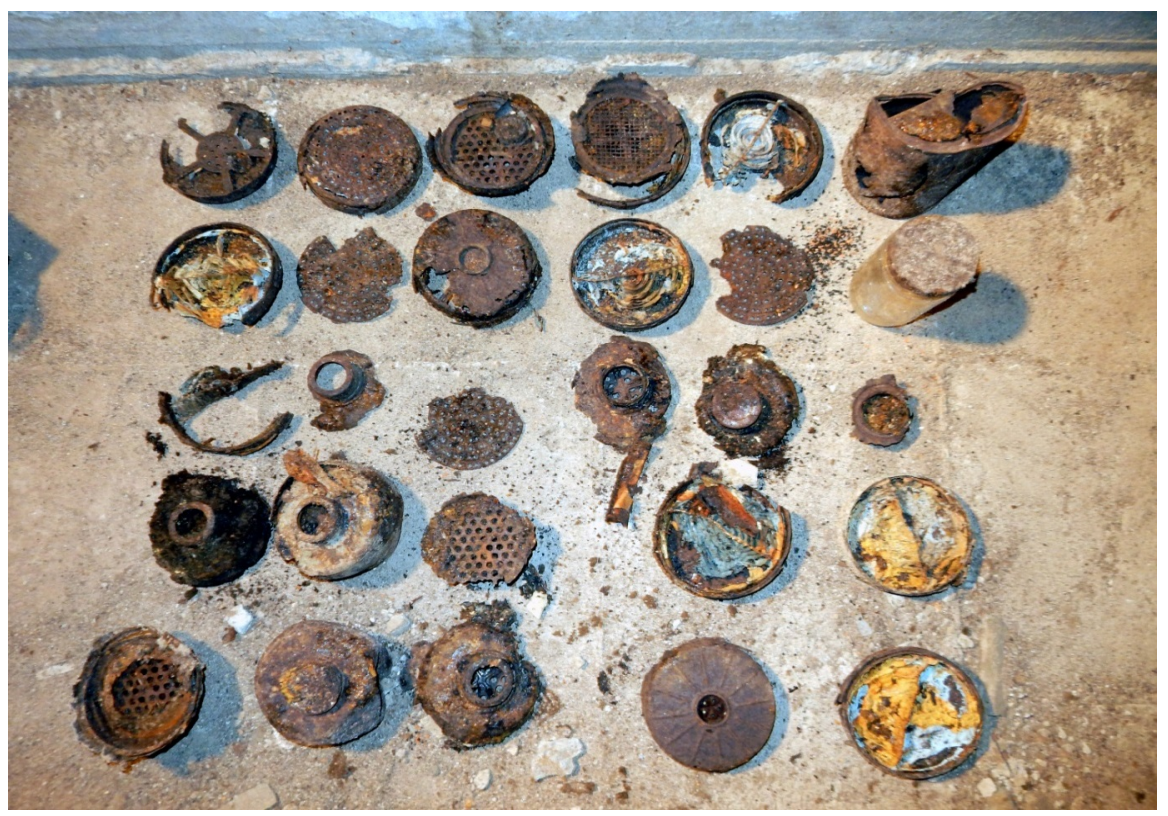

(a)

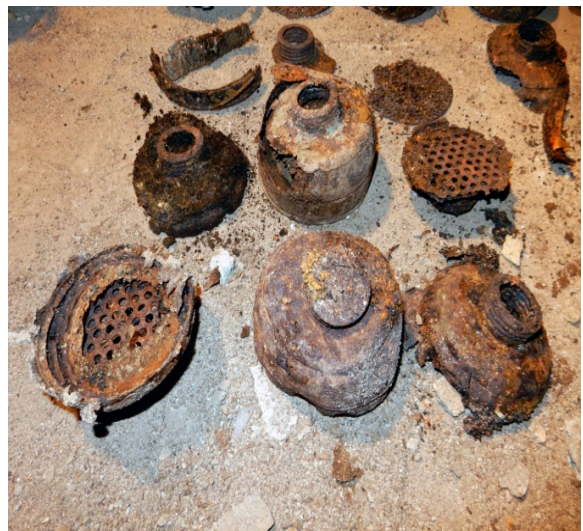

(b)

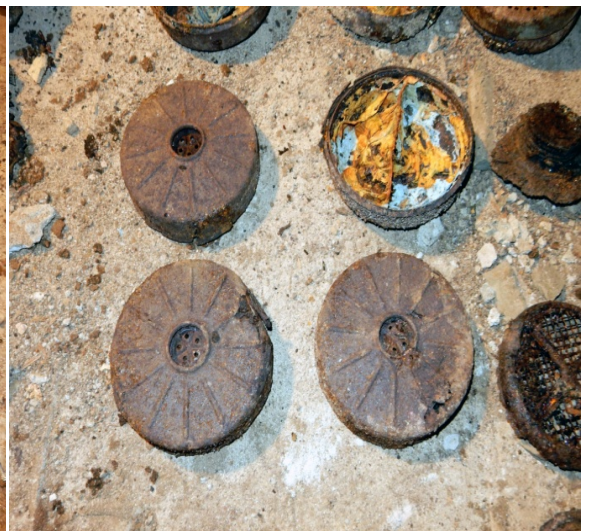

(c) 


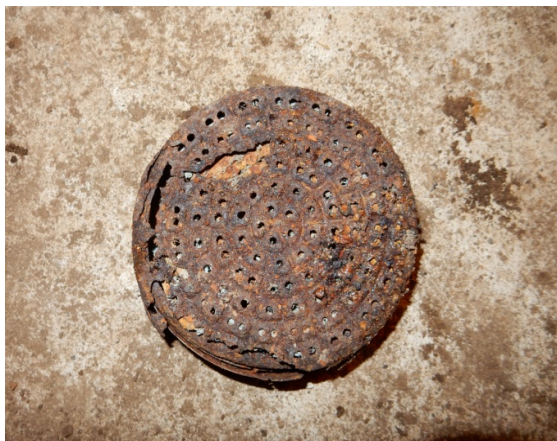

(d)

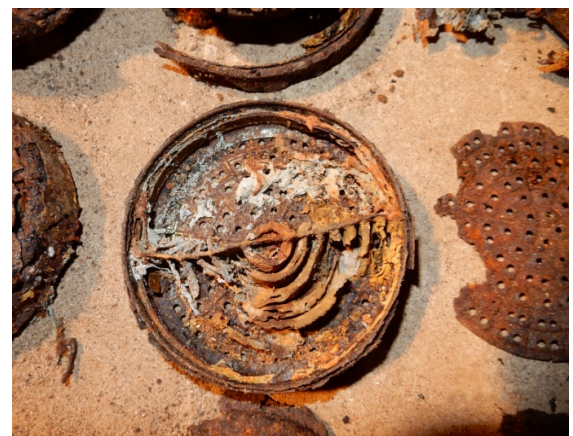

(f)

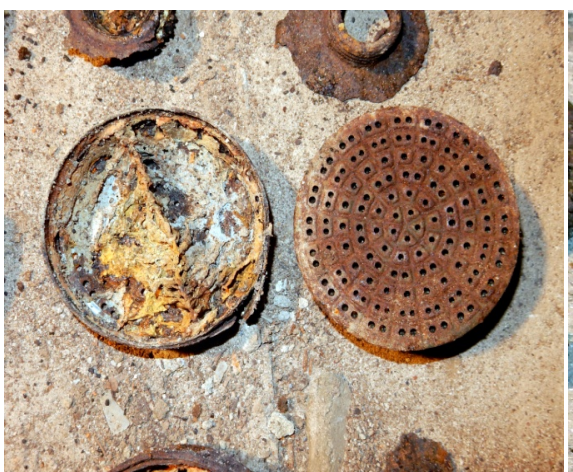

(h)

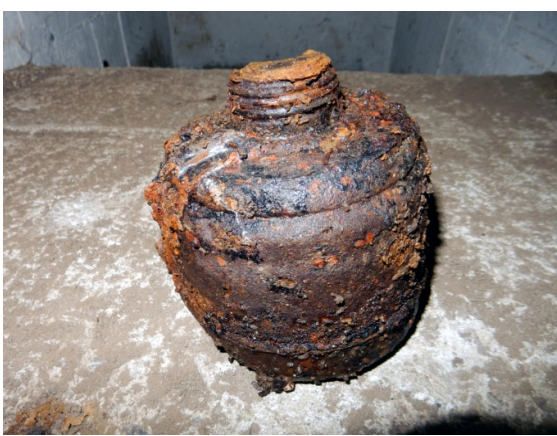

(j)

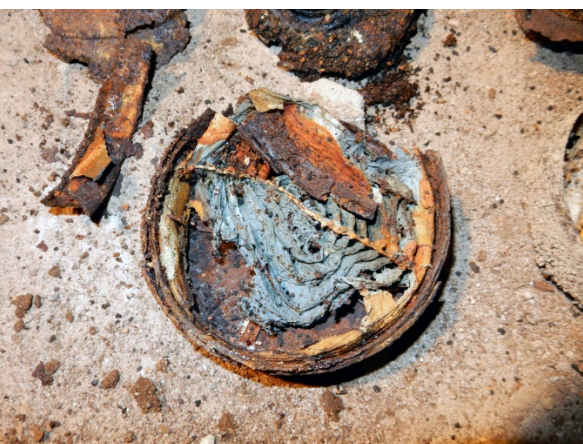

(e)

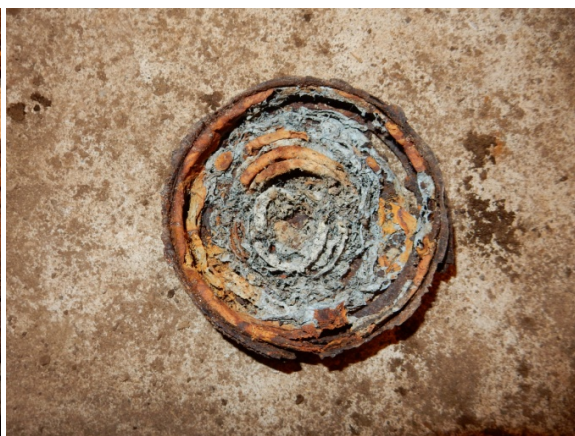

(g)

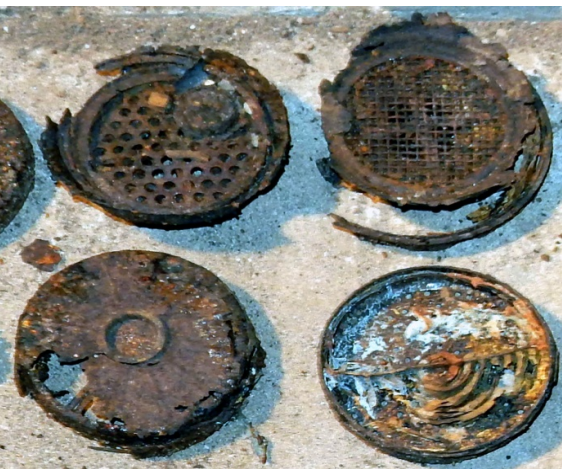

(i)

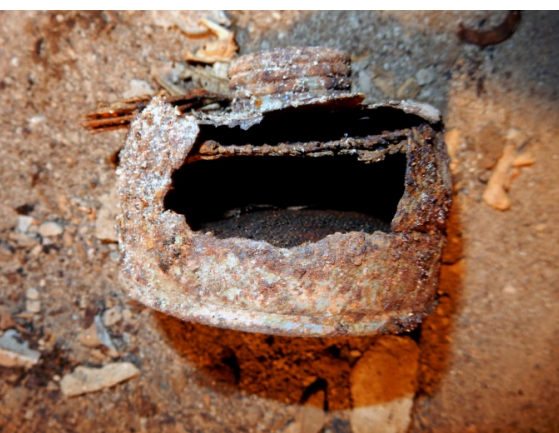

(k)

Figure 7. L 479 discovered components of gas mask filtering cartridges (a) Overview; (b) Covers and pots of unknown filtering cartridges; (c) Upper line: FE 39 cover and unknown type cover, lower line: FE 42 covers; (d) FE 37 cover; (e) Unknown cover; (f) Unknown cover; (g) Unknown cover; (h) Unknown cover and $F E 37$ cover; (i) Upper line: unknown covers, lower line: $F E 41$ cover and unknown cover; (j) Complete $F E 37$ filtering cartridge; (k) Complete $F E 41$ filtering cartridges. 
Other discovered items of minor interest were:

- a barbed wire stretch (Figure 6(h)) found at the lower side of the stair, probably part of the original camp barrier,

- one rusted cartridge for $20 \mathrm{~mm}$ gun (Figure 8(a)),

- one pork shank (Figure 8(a)),

- four small bottles without marks of unknown origin and content (Figure 8(b)),

- a degraded stretch of electrical cable with sheath and three conductors (Figures 8(c)-(d)),

- two completely rusted jars (Figures 8(e)-(g)),

- one radio tube (Figure 8(f)), without marks probably of the years 50 - 70, found near the upper side of the stair,

- a pail blue coloured bucket, about $50 \times 30 \mathrm{~cm}$, of unknown origin, found in the telephone exchange room together with the filtering cartridges (Figure $8(\mathrm{~h})$ ).

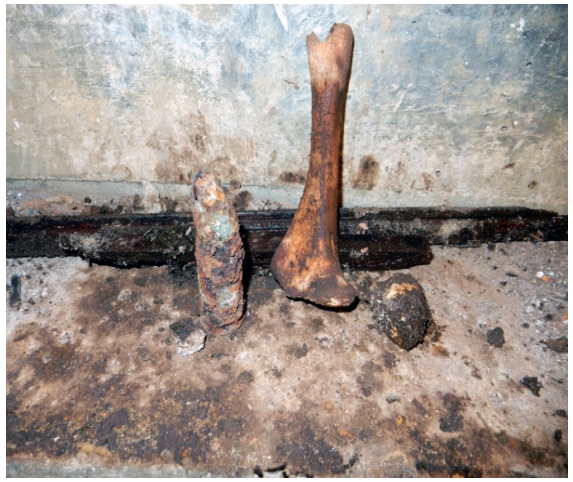

(a)

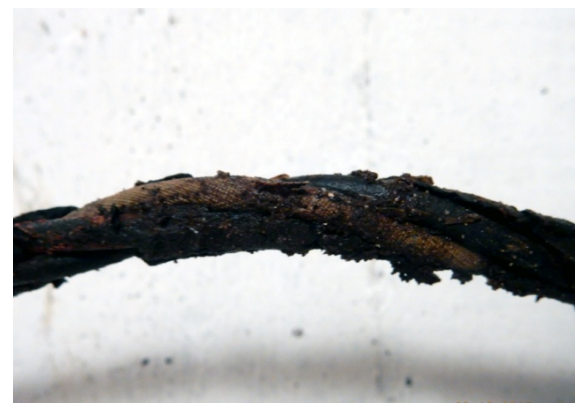

(c)

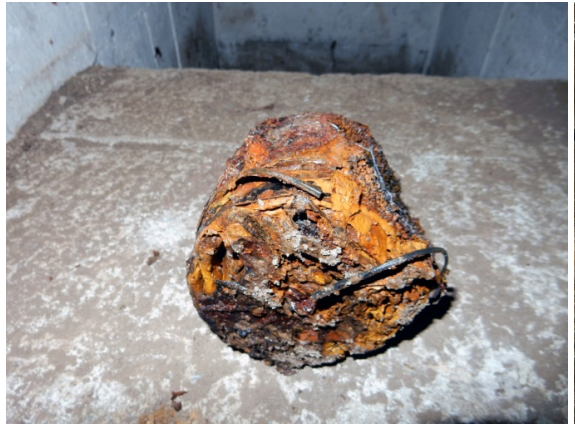

(e)

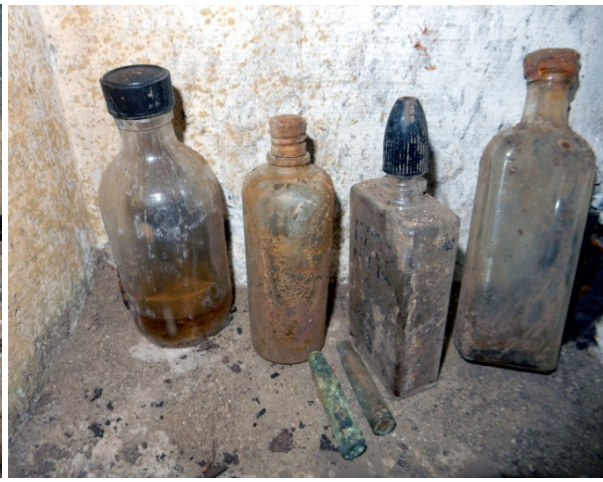

(b)

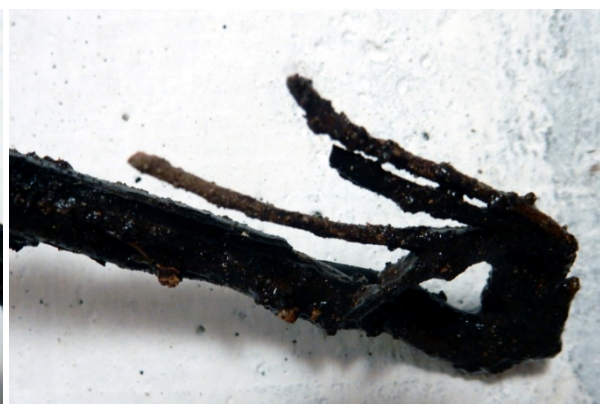

(d)

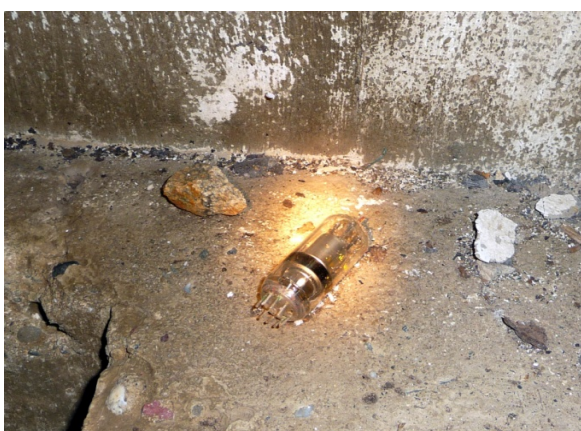

(f) 


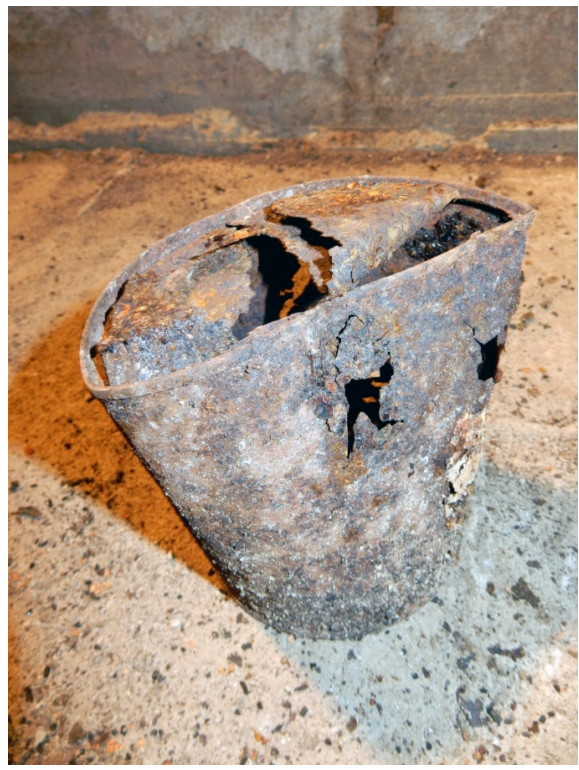

(g)

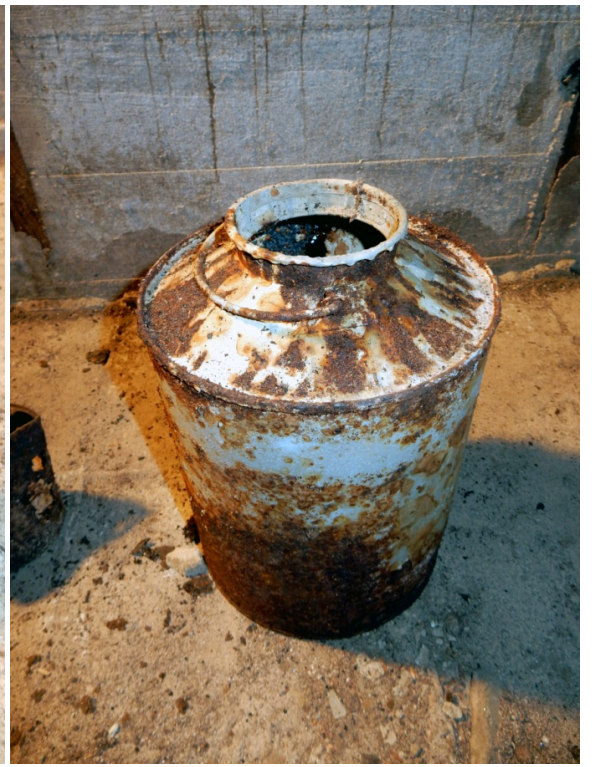

(h)

Figure 8. L 479 other discovered items: (a) Rusted cartridge for $20 \mathrm{~mm}$ gun and pork shank; (b) Small bottles without marks; (c)-(d) Degraded stretch of electrical cable; (e) Rusted jar; (f) Radio tube; (g) Rusted jar; (h) Pail blue coloured bucket.

\section{Discussion}

The sites A, C, D, the main sites of Target VI/1, each hosting a radar. For their importance they were protected by at least one close defence machine gun position. The anti-aircraft defence was assured by three light anti-aircraft gun emplacements indicated as Light A. A. (about $48^{\circ} 34^{\prime} 8^{\prime \prime} \mathrm{N}, 4^{\circ} 36^{\prime} 59^{\prime \prime} \mathrm{W}$ ). The buried cable trenches connecting the sites (Figure 2) originated from site $\mathrm{C}$, suggesting for its two barracks a commandment and coordination function. The camp power supply was derived by the French public net. The organization of the services and living conditions at the radar camp remain to be investigated.

The two Freya and the FuMG 39 Tradars of the Luftwaffe were installed in the period $16^{\text {th }}$ June- $31^{\text {st }}$ October 1941 and operated at least from this period. Their installation was in relation with the necessity of protecting the presence from $22^{\text {nd }}$ March 1941 in the port of Brest of the Scharnhorst and Gneisenau. A report of $17^{\text {th }}$ July 1940 by R. V. Jones of the Scientific Intelligence Service already signalled a Freya radar in the region of Brest. It is possible that it was installed at Saint-Pabu. The Freya radar of the Kriegsmarine was installed on $18^{\text {th }}$ January 1942 (Blanchard, 2017). Not mentioned as components of Target VI/1 the two Würzburg-Riese radars, the $L 479$ and the other bunkers of the radar camp, cover name Pinguin (Tomezzoli \& Colliou, 2017), were deployed after $10^{\text {th }}$ January 1942. The Kriegsmarine radar FM 24 installed at the camp north side probably substituted the $W 510$ positioned at site $\mathrm{D}$ at the same camp north side.

Although the $L 479$ had gas lock rooms provided with airtight doors, the presence of gas filters at its interior is not surprising because they were normal components of the standard German soldier equipment. The reason for which 
they were accumulated in the telephone exchange room of the ground floor is a mystery.

The fact that the camp was surveilled and the $L 479$ found emptied of its original furniture, suggests that it was not looted by the population, but acquired by the American or French Army, including sensitive furniture like radios, telephones and the Seeburg tables.

The organization of the activities performed at the $L 479$ in connection with those of the radar stations at KeringarVihan, Kervingam-Kerdené, Vougo-Kerizoc (Tomezzoli, 2017a), at the coastal artillery battery HKB 1274-C 342 at Camaret-sur-Mer (Tomezzoli, 2017b), FuMB 686 Wolga (Tomezzoli, 2017c), Re 311-FuMB 445 Donau (Tomezzoli, 2017d) and those of the other nearby day and night fighter control centres Qu13Renntier at Lescoff (Finistère), La 318Froschat Cap Fréhel (Côtes-d'Armor), Mo 9aPfauenauge at Mez-Gouez (Côte d'Armor) and Rennes, St-Jacques-de-la-Landes (Ille-et-Vilaine) (Dupont et al., 2007) need further investigations.

\section{Conclusion}

As usual in this kind of researches, the acquisition of new evidences answered questions and clarified evolution aspects of the Saint-Pabu radar camp, but inevitably these advancements in the knowledge led to further questions, as those we come to mention. Interdisciplinary contributions of experts in different fields and witnesses will certainly help, as in this case, to answer said questions.

\section{Acknowledgements}

We thank very much Mr. Blanchard for sharing us the results of his studies in the Doll archive concerning the early evolution of the Saint-Pabu radar camp, Mr. Fleuridas for the authorisation to reproduce in this article his $L 479$ plan and Mr. Haas for his researches in the Bundesarchiv-Militärarchiv (BAMA) of Freiburg (DE) concerning the radar camp.

\section{References}

Blanchard, Y. (2017). Situation des Radars de Saint-Pabu en décembre 1941. Unpublished Note.

Colliou, S. (2017). Les Bunkers de Saint-Pabu. Brest: PAM.

Doll, M. (2017). Personal Archive.

Dupont, Ph., Fresil, Y., \& Tomezzoli, G. (2007). Deutsche Militärbautenbei Rennes, DAWA Nachrichten, Ausgabe 49. Köln: Verlag Harry Lippmann, 56-66.

Fleuridas, P. (2017). Personal Archive.

Rudi, R. (1988). Typologie du Mur de l'Atlantique. Beetsterzwaag, ISBN 9064760453, NUGI 923.

Tomezzoli, G. T. (2017a). The German Radar Surveillance around the Aber Wrach during the WW II. Archaeological Discovery, 5, 22-41.

https://doi.org/10.4236/ad.2017.51002

Tomezzoli, G. T. (2017b). The WW II German Coastal Artillery Battery H.K.B.1274/StP 
C 342 at Camaret-sur-Mer (Finistère-FR). Archaeological Discovery, 5, 116-141. https://doi.org/10.4236/ad.2017.53008

Tomezzoli, G. T. (2017c). The WW II German Stützpunkt on the Menez-Hom (Finistère-FR). Archaeological Discovery, 5, 224-237. https://doi.org/10.4236/ad.2017.54013

Tomezzoli, G. T. (2017d). The WW II German Defences Structures around Ploumoguer (Finistère-FR). Archaeological Discovery, in Press.

Tomezzoli, G. T., \& Colliou, S. (2017). The WW II Saint-Pabu German Radar Camp and the Stutzpunkte Re 03, Re 04. Archaeological Discovery, 5, 142-162.

https://doi.org/10.4236/ad.2017.53009 